\title{
The Value of Critical Pedagogy in Mass Education for Reducing Illiteracy in South Africa: Kha Ri Gude Current Realities and Prospects
}

\author{
Mpho M. Dichaba \\ Joyce P. Dhlamini \\ Dept. of ABET \& Youth Development, College of Education \\ University of South Africa \\ Email address: dichamm@unisa.ac.za
}

\section{Doi:10.5901/mjss.2013.v4n3p401}

\section{Abstract}

The paper investigates the challenges and prospects for cascading mass literacy campaign in South Africa. This paper is underpinned by Paulo Freire's theory of critical pedagogy. The key elements of critical pedagogy are analysed in terms of its potential for improving the Kha Ri Gude mass campaign. Constraints in the current situation are also described. The paper looks at the current realities in the Kha Ri Gude campaign, the progress made and the opportunities available, as well as the identifiable gaps and proposals for closing these gaps. The paper concludes that the challenges are formidable, but that the project allows the learners to step over the illiteracy threshold into a world that is immeasurably richer in meaning in which they can act and transact as never before. Learners consequently receive their certificates with pride and gratitude as their first indication of success in their lives and realisation of the potential they possess.

Keywords: literacy campaigns, volunteers, Kha Ri Gude, Adult Basic Education and Training, critical pedagogy.

\section{Introduction and Background}

The Bill of Rights in South Africa enshrines the right of all citizens to basic education, including Adult Basic Education $(A B E)$, which must, through reasonable measures, be made progressively available and accessible to everyone (Department of Education, 1997). Therefore, Adult Basic Education and Training (ABET) forms an integral part of the government's educational redress and transformation initiatives in adult education communities, technical colleges and universities (Flavis \& Omar 1995:3). Realising the need for literacy and numeracy, many NGOs and some education institutions in South Africa have either started ABET programmes for their employees or encouraged them to take parttime courses in order to upgrade their skills (Quan-Baffour, 2000:3). This is an attempt to meet the ABET learners' dual need for both basic education and income generation. Apart from skills training, ABET learners also receive general lifeskills education which is tailored to respond to the needs of their age group and relevant to the communities in which they live. HIV and Aids training, in particular, features prominently in ABET curricula.

\section{Theoretical framework}

This study is underpinned by the theory of critical pedagogy. The authors of critical pedagogy include Freire (1972), Apple (1995; 2003; 2004), Giroux (1988; 1999), Darder (1991), bell hooks (1994; 2003), Kincheloe (2004), Zinn (1995), among others. Freire $(1970 ; 1974 ; 1993)$ is considered to be the inaugural philosopher of critical pedagogy (McLaren, 2000). It is worth noting that the original Brazilian education projects that led to the publication of Freire's (1970) Pedagogy of the oppressed were centred on literacy education. For Freire (1970), critical pedagogy is concerned with the development of conscientisation, usually translated as "critical consciousness". Freire (1970) valued the importance of student experience and a dialogical method of teaching and learning whereby the student and the teacher were mutually engaged in the production of knowledge and the process of teaching and learning. For Freire, the task of critical pedagogy is to bring members of an oppressed group to a critical consciousness of their situation as a starting point of their liberatory praxis. In accordance with this notion, Freire (1993) affirms that the essence of education is the practice of freedom, dialogics and dialogue, which are the awakening of critical consciousness through the investigation of generative themes. Authentic education is not about one teaching for or about another; authentic education needs to consist of one teaching 
and learning with another in order to hear and value the life experiences and realities of all of those in the educational process so as to gain a more holistic awareness of humanity (Freire, 2007).

According to Darder (1991:77), critical pedagogy should seriously address the concept of cultural politics by both legitimising and challenging cultural experiences that compromise the histories and social realities that, in turn, compromise the forms and boundaries that give meaning to students' lives. The intention of critical pedagogy is to contribute to a more socially just world (Kincheloe 2004). For Giroux (1988:177), the role of the critical educator should be to raise ambitions, desires and real hope for those who wish to take seriously the issue of educational struggle and social justice. According to Freire and Macedo (1987), the method of critical pedagogy involves "reading the world" as well as "reading the word".

\section{Literacy Defined}

It is difficult to simply give a definition of literacy since understanding of literacy needs to reflect the views, attitudes, values and goals of those who happen to be within a particular context (Smythe, in Alkenbrack, 2001:113). Traditionally the concept literacy was considered to be an individual's ability to read (National Institute for Literacy, 1998). Contemporary definitions extends literacy to mean a person who is literate can both read and write a short simple account of his everyday life with understanding (UNESCO, 2006). More recently literacy has been defined as a social practice (Janks, 2010:2). This means that literacy is fundamentally a social activity, primarily participation by an individual in a set of socially organised practices. It is a complex amalgam of psychological, linguistic and social processes. Furthermore, literacy is a continuum ranging from the first hesitant formation of the letters of one's name to the ability to read and write abstract texts.

Hutton (2002:40) states that in most countries government agencies provide and control most aspects of the provision of literacy. Literacy standards vary from country to country according to the demands of that country, also according to the resources available for adult education. For example, in the USA someone could be defined as being functionally illiterate but would pass as literate in a poor country which was struggling to improve very basic literacy levels. In South Africa literacy is viewed from a different angle. In the years prior to the arrival of democracy in South Africa, literacy was conceptualised very narrowly; after 1994 it became urgent for the government to address the education deficiencies of thousands of black adults who were functionally illiterate.

The term "literacy" is often loosely used to include basic competency in English. According to Terryn (2003), this definition of literacy is very limiting and also makes no allowance for the different types of literacy skills needed for work or for family life, nor for numeracy. The definitions of literacy are, however, complicated by the fact that knowledge of a second language, usually English, is as vital for survival and development as the ability to read and write in an African language. The main aim of literacy learning programmes is to encourage the use of literacy skills in daily lives rather than the learning of literacy skills in the classroom (Roger, 2002:25). Sibiya and Van Rooyen (2005:480) maintain that reading and writing skills can lead to one sort of literacy, but functional literacy is broader in its conception. In 2009, some $7 \%$ of the adult population in South Africa (people aged 20 and above) were totally illiterate and $12 \%$ were functionally illiterate. This means that approximately 5, 5 million adults were either totally or functionally illiterate in 2009 (Department of Education, 2009).

Given such a situation prevailing among the citizens of South Africa, the government declared its intention to provide a democratic environment for all citizens. An attempt to ameliorate the high rate of functional illiteracy among blacks in South Africa was thus begun. Subsequently, the South African Department of Education (DoE) embarked on a massive literacy campaign. The overall objective of the campaign was first and foremost to reduce significantly the levels of functional illiteracy among South Africans. The second objective was to increase the participation of all the people in the social, cultural and economic spheres of society by providing literacy classes to those adults with little or no schooling (Department of Education 2001). The third objective was to educate the voters for the 2004 elections. It was hoped that by increasing citizens' functional literacy, the literacy campaign would have a positive effect on the democratic state. This is in line with Paulo Freire's (1974) notion that the theory of critical pedagogy is a call for reflection on and action in the world in order to transform it. According to Freire (2007:72), apart from inquiry and praxis, individuals cannot be truly human. In this case, for individuals to become truly human, education should be the practice of liberation where individuals deal critically with reality and discover how to participate in the transformation of their lives (Dader, 1991). Research by Oxenham et al. (2002) on ABET and improved livelihoods found that ABET learners generally perceive literacy and numeracy as

- protection against being cheated and manipulated in the market place 
- skills to quantify gains in lifetime income

- getting access to credit

- an entry into vocational skills training

- realising tangible short-term incomes

On the basis of the above statement, Freire's (1970) emphasis on dialogue enabled the educators to develop lessons based on the needs and interests of the learners in order to invite them to take part in a larger community discourse that attempts to solve problems and create alternatives for oppressive situations. In his statement, Freire (2007:92-93) points out that without dialogue there is no true communication and without communication there can be no true education.

\subsection{Literacy campaigns in South Africa}

The South African government recognised that a lack of literacy has impacted on the development of the country as a nation and consequently decided to launch a campaign to fast-track literacy delivery. Literacy classes in South Africa, for example, the South African National Literacy Initiative (SANLI) and Kha Ri Gude, which are discussed in subsequent paragraphs, may involve anything from basic skills in reading and writing in a person's mother tongue, to fairy advanced English second language classes where the nature of democracy is discussed (Hutton, 1992:11). Freire (2007) states unequivocally that teaching and learning are human experiences with profound social consequences. Therefore, the Kha Ri Gude campaign enables learners to read, write and calculate in their mother tongue in line with the unit standards for ABET Level 1. They also learn to speak English. The campaign relies on the services of volunteer educators, supervisors and coordinators to give their time to provide literacy classes. These volunteers are expected to recruit learners to participate in learning. Paulo Freire's approach (1970) to fostering literacy also combined the development of basic skills in reading and writing, the development of a sense of confidence and efficacy, especially in collective thought and action; and the desire to change, not only one's self, but the circumstances of one's social group.

\subsection{South African National Literacy Initiative (SANLI)}

In 2001, the national Department of Education under Professor Kader Asmal launched the South African National Literacy Initiative (SANLI) as part of Tirisano, the National Education Strategy (DoE, 2007). SANLI oversees the establishment of a voluntary service to reach the 3,2 million illiterate adults in South Africa and caters for pre-ABET and ABET Level 1 learners (DoE 2003:244). The aims of the programme as stated by McKay (2007:300) were the following:

- to reduce by 2004 illiteracy levels in each province by at least $35 \%$

- to enable the majority of newly literate adults to take up referrals to further education and economic opportunities

- to ensure that $60 \%$ of newly literate adults maintained their skills by keeping contact with and accessing materials in the local resource centres and community development projects

SANLI targeted the mobilisation of illiterate adults in order to eradicate illiteracy. Thus the University of South Africa-SANLI initiative was formed (DoE, 2006: 19). The partnership aimed at recruiting adult facilitators for the programme and to start by training them (DoE, 2007d). This training focused on equipping the facilitators with the relevant skills and facilitation methods that would motivate adult learners to participate in the learning programme. It is important that the facilitators be trained in the entire management process of adult learning.

More recently, government's mass literacy campaign, Kha Ri Gude (Let us learn), offers lessons at 22000 sites, involving about 328000 adult learners of various ages (DoE, 2007d). The five-year campaign aimed to have 4, 7 million adults become literate by 2012. The South African government's Kha Ri Gude mass literacy campaign uses the cascade model to train literacy educators in five-day courses. In terms of this model, coordinators train supervisors to train literacy educators.

\subsection{Kha Ri Gude literacy campaign}

Kha Ri Gude is a Venda word that means "let us learn". The South African Department of Education (2011:3) reports that the Ministerial Committee on Literacy (MCL) was established by the Minister of Education, Minister Naledi Pandor, in February 2006. This MCL was tasked with developing strategic plans for a mass literacy campaign to enable about 4, 7 million illiterates, who had never been to school, to achieve a level of basic literacy. In 2008, as part of the plan, the 
projected learner participation was targeted at 275000 learners. Subsequently, the Kha Ri Gude (Let us Learn) South African Mass Literacy Campaign was launched in 2008 in all nine provinces of South Africa as a national programme of government intended to end illiteracy among South African adults and to make manifest the right of all citizens to a basic education in the official language of their choice.

\subsubsection{Preparing the volunteer educators for their roles}

Kha Ri Gude uses approximately 40000 volunteers to offer their services to reach and teach more than 600000 learners each year (DoE 2008). During 2008 more than 35000 people young and old volunteered to teach 360000 learners. In 2009 and 2010 more than 40000 people volunteered to teach 614000 learners and between the years 2011 and 2012, a further 620000 adult learners benefited from the campaign. The volunteer educators start by undergoing training on how to manage Kha Ri Gude. They are expected to remember that most learners were previously denied schooling for a range of reasons, and that this is their chance to receive some form of education. It is worth noting that educators have the potential to be what Giroux and McLaren (1996) describe as transformative intellectuals who combine scholarly reflection and practice in the service of educating students to be thoughtful, active citizens (Giroux, 1988:122). In the same vein, McLaren (1988) opines that the fundamental commitment of critical educators is to empower the powerless and transform those conditions which perpetuate human injustice and inequality. In this case, Kha Ri Gude volunteer educators have a central role to play in the development of South Africa through literacy and, in turn, in South Africa's achievement of the Millennium Development Goals (MDGs). In order to help the learners, the educator must create an active learning environment in which students can accomplish all of the steps needed to reach that goal (Michael, 2004).

Freire (1972) was firmly on the side of a pedagogy that begins by helping students to grasp the concrete conditions of their daily lives. He emphasised "reflection" in terms of which the student assimilates knowledge in accordance with his/her own needs, rather than didactic, "chalk-and-talk" learning. Another aspect that Kha Ri Gude volunteer educators are trained in is making learning meaningful to the learners. Instead of transferring facts and skills from teacher to students, a Freirean class invites students to think critically about subject matter, doctrines, the learning process itself and their society. Action projects that improve a learner's livelihood or help resolve local problems will attract more learners to participate in literacy campaigns.

The Kha Ri Gude volunteer educators hold classes three times a week at times which are convenient to the learners, in venues such as homes, churches, mosques, schools and community centres that are close to where learners live. Classes provide 240 hours of contact tuition. Paulo Freire (1993) and Hoardley and Jansen (2004) maintain that the curriculum content should be drawn from students' lives and be developed with them in an interactive and critical manner, which would lead to empowerment. This is in line with Kha Ri Gude in that teachers are encouraged to discuss local issues with the learners, especially matters like HIVIAIDS and crime. The crucial question is whether such initiative will be sustainable to enable adults to expand the knowledge to the other members of the community for transformation and empowerment. Too many people in South Africa have both HIV and TB, about $70 \%$ of people with TB are also HIV positive (Equal treatment, April 2013). According to Freire (1970) conscientising learners and making them aware of the reality can help them to live a dignified life. For instance, each volunteer educator is advised to enrol 18 learners who cannot read or write. When enrolling learners, Kha Ri Gude volunteer educators are expected to ask them what they want to learn, and try to help them learn this during the programme. Paulo Freire (1993) believes that dialogue involves respect for human beings. Therefore, Kha Ri Gude volunteer teachers are expected to encourage learners to become involved in an income-generating project. For instance, learners are encouraged to develop vegetable in communities where they live. The fresh produce from their gardens are taken to the small markets within their community for sale. There are cooperatives that have been formed through collaboration in the skill development programmes offered by Kha Ri Gude especially to the unemployed. This is in harmony with critical pedagogy which suggests that adults learn best when instruction is contextualised in their life experiences and related to their needs.

Freire (2007:35) notes the importance for students to develop what he refers to as "conscientização", which is the "process of learning to perceive social, political, and economic contradictions, and to take action against the oppressive elements of reality. Freire's emphasis on conscientização calls for educators to develop lessons based on the needs and interests of the learners to invite them to take part in a larger community discourse that attempts to solve problems and create alternatives to oppressive situations. For instance, Kha Ri Gude volunteer educators are expected to motivate learners to attend all their classes and to complete the programme. Furthermore, Kha Ri Gude trains volunteer educators to understand how to use the learning material, namely, the facilitators' notes, and to link it to the learners' manuals, mother tongue literacy material, the English for all learning material as well as learner's assessment portfolios, and to 
offer classes in all eleven official languages as well as Braille and sign language. They may use additional learning material such as forms, recipes and instructions.

\section{The use of the cascade model in the management of Kha Ri Gude}

Kha Ri Gude volunteers, comprise 44 monitors, 203 coordinators, 3703 supervisors and 38407 volunteer educators, including 250 helpers for blind volunteers (Motsekga, 2013). Kha Ri Gude uses a cascade structure to manage and organise its classes. For instance, if there are 38407 volunteer educators, it means that there are 38407 Kha Ri Gude classes that are run each year. Considering this volume it was necessary to design a structure for managing the quality of the campaign implementation. The cascade structure is illustrated in the diagram below which is replicated about 200 times across the country. This simply means that there are 200 such cascades spread across each of the nine provinces.

Figure 1: Kha Ri Gude structure

\begin{tabular}{|c|c|c|}
\hline $\begin{array}{c}\text { Portfolio of } \\
\text { Volunteer }\end{array}$ & $\begin{array}{c}\text { Number of } \\
\text { Volunteers }\end{array}$ & $\begin{array}{c}\text { Total Number of Volunteer } \\
\text { Educators per Category }\end{array}$ \\
\hline Coordinator & 1 & 1 \\
\hline Supervisor & 20 & 200 \\
\hline Volunteer educator & 10 & 200 \\
\hline Learners & 18 & 3600 \\
\hline
\end{tabular}

The above table shows that a coordinator is responsible for 20 supervisors. Each supervisor has 10 volunteer educators (VEs) for whom he/she is responsible, which gives a total of 200 VEs. Finally, each VE is expected to recruit 18 learners to qualify for a class. In total this cascading model allocates 3600 learners per coordinator. There are various roles that each volunteer is expected to perform in order to enable the functioning of the campaign.

\section{Current Realities: The Progress made and Opportunities Available}

Kha Ri Gude was introduced in 2008 and has up to now shown that it is yielding good results, reaching 613000 adults in 2009. One of the key factors not addressed by the government, however, was the very marked differences in the numbers of adults who enrolled in the campaign in rural and urban areas. The campaign has equipped many South Africans with a variety of skills such as reading, writing, numeracy and entrepreneurial skills. Each and every adult learner receives a well-prepared pack of learning material together with stationary, including calculators for numeracy, coloured pens to distinguish between colours, exercise books for practising writing, workbooks for practicing reading and an English workbook. Despite the fact that no formal classrooms are used for tuition, Kha Ri Gude continues to exist under trees, in volunteers' houses and garages. The slogan employed by the project, which says "Kha Ri Gude wherever you are" has brought it tremendous success. Between the inception of the programme and March 2011, approximately 1, 5 million learners became literate (DoE, 2012). This shows that Kha Ri Gude has played a role in achieving the MDGs for South Africa, one of which is the eradication of extreme poverty and hunger. For instance from 2010 to March 2011, 609199 learners successfully completed the programme (DoE, 2012). This means that project is also achieving its objective of eradicating illiteracy million in South Africa as discussed above.

The learner assessment employed has been successful in terms of the manner in which it is applied. Portfolio assessment affords an extended opportunity to display evidence of the tasks and activities that adult learners can perform. The notional time that is allocated to the project is in line with the requirements of the South African Department of Basic Education. Finally, each Kha Ri Gude learner receives a certificate of competence that proves that learner can continue to ABET Level 2.

\section{Learner Assessment in Kha Ri Gude}

Learner assessment forms an integral part of learning and standardised testing is receiving increasing interest among adult literacy educators. Moreover, portfolios have the potential to document a wide range of outcomes not assessed by typical literacy tests. Other potential benefits have also been ascribed to portfolio assessment, including more concrete evidence of learners' progress, enhanced learner self-direction and responsibility for learning and greater integration of assessment and instruction (Gillespie, Ford, Gillespie \& Leavell, 1996). The assessment of learning is an important and 
inevitable part of any educational activity, whether it is done informally, non-formally and formally. According to Boud and Falchikov (2007) and Joughin (2008), assessment plays a role in the development and practice of making a judgement. It is therefore the process of getting information about what a learner knows or can do and then using that information as evidence for making a judgement about the learner's achievement.

Kha Ri Gude engages portfolio assessment called Yes I Can in order to evaluate learners' success. Jones and Shelton (2006:23) state that a portfolio is a record of evidence of a learner's learning efforts over time. It is an alternative assessment that provides a profile of a learner's learning achievements, in particular skills and knowledge. According to Palomba and Banta (1999:131), a portfolio is a type of assessment in which learners' work is systematically collected and carefully reviewed for evidence of learning and development. The Yes I Can comprises 20 assessment activities, each testing one level of learning outcomes in mother tongue communication and numeracy. Activities are graded from easy to more complex. Within a few weeks of starting, learners should be ready to do the first communication and numeracy assessment tasks. The portfolio document suggests when learners should be ready to attempt each activity, although it might not be all the learners who will be ready for the assessment task. At the end of the programme, each educator collects the assessment portfolios from the learners and marks them on site. Those portfolios are then moderated by the supervisors, verified by the coordinators and then sent for external verification by SAQA. All the successful learners have their records uploaded onto SAQA National Learners' Records Database (NLRD). This process serves as an important component of assuring governance and accountability and of monitoring teaching and learning (Department of Basic Education 2010).

\section{Constraints of the Kha Ri Gude Campaign}

Numerous problems are experienced by adult learners in mass literacy campaigns. A few are discussed below:

\subsection{Problems with the learning material}

Learners receive their learning material late. Since it started, the Kha Ri Gude campaign is supposed to commence on 1 June of each year. Often learners receive their material after the starting date; some up to two months after the official start of the programme. Educators then have to rush their teaching process in order to be able to complete their tasks within the scheduled period of six months as mentioned above. Learners are then at a disadvantage as some cannot learn fast.

\subsection{Learner absenteeism}

The majority of adult learners are above the age of 50 . Given this age they may have chronic ailments such as high blood pressure and may need to attend to their routine treatment at the clinic. This often consumes the time they should be in class. However, volunteer educators can schedule their classes in such a manner that days for clinic visits are not included in the programme. This will need the discussion between the educator and the learners to draw a schedule together. Learners may also experience family problems. As South Africa is severely affected by HIV and AIDS, adult learners are also affected. Moreover, family members are sometimes sick and they have to look after them. Teenage pregnancy also affects adult learners, as their daughters may fall pregnant whilst still at school and have babies who have to be looked after then the mother goes back to school.

\subsection{Time frames of the programme}

Since its inception in 2008 Kha Ri Gude has operated for six months of each year. Accordingly, 240 notional hours are allocated by the DoE to ABET Level 1. This allocation often presents problems for the adult learners as their cognitive capacity is low and they find it difficult to achieve the outcomes as set out for the programme and complete the total of 85 lessons (Department of Basic Education, 2007:1a).

\subsection{Problems with the venue}

Venue is one of the challenges that volunteer educators' experiences. Some classes operate from peoples' properties such as their homes, garages and empty rooms. The landlords expect them to pay rental for the venue and if they do not 
have it they will be chased away. Some classes operate on school premises. However, during school holidays some principals do not allow classrooms to be used as this raises security issues. Classes then cannot operate.

\section{Identifying and Closing the Gaps}

Attempts to improve mass literacy campaigns are dependent on improving the management aspects of the project. The period given for the ordering of learner material should be improved. If the programme has to start in May each year, then that means the ordering of learner material has to be done as early as January of that year. In addition, enough time should be allowed for the delivery of stationary so that the 240 notional hours is used fruitfully. This will allow the volunteer educators to distribute the material on time.

Freire (2005:40) clearly states that to study is to uncover; it is to gain a more exact comprehension of an object, it is to realise its relationship to other objects. The mission of volunteer educators in the Kha Ri Gude campaign is to assist adult learners in achieving and developing their full potential as intellectual, psychological and emotional beings. For a Kha Ri Gude learner, learning must lead to meaningful transformative action. For instance, learners should be encouraged to start their own projects using the skills that they have gained from the project. Accordingly, they can start cooperatives, such as gardens. The produce from these gardens can be taken to market and also used to feed their families. The numeracy skills learnt from the project can be used to start small business and become entrepreneurs. They might not even want to go for seasonal employment in the neighbouring farms because they will do farming for themselves and earn a living. Ciardiello (2004:138) suggests that critical literacy is a "set of practices and civic competencies that help the learner develop a critical awareness that texts represent particular points of view while often silencing others"

\section{Conclusion}

This article has discussed the value of critical pedagogy in reducing illiteracy in South Africa through mass education so as to solve problems and create alternatives to oppressive situations. Using Kha Ri Gude as a context, the researchers canvassed the current realities, the progress made and the gaps and made a number of proposals for closing the gaps in the Kha Ri Gude campaign. Paulo Freire's insistence on situating educational activity in the lived experiences of participants has opened up a series of possibilities for the way Kha Ri Gude volunteer educators can approach education. Given the pace of this improvement, it is likely that Kha Ri Gude in South Africa will reach the Education for All goals for literacy by 2015.

\section{References}

Apple, MW. (1995). Education and power. New York: Routledge.

Apple, MW. (1999). Power, meaning and identity. New York: Peter Lang.

Apple, MW. (2000). Official knowledge: democratic education in a conservative age. New York: Routledge.

Apple, MW. (2004). Ideology and curriculum. New York: Routledge Falmer.

Boud, D \& Falchikov, N. (2006).Aligning assessment with long term learning. Assessment and Evaluation in Higher Education 31(4):399-413.

Campbell, P. (2007). Measures of success: Assessment and accountability in Adult Basic Education. Edmonton, Alberta, Canada: Grass Roots.

Ciardiello, A.V. (2004). Democracy's young heroes: An instructional model of critical literacy practices. The Reading Teacher, 58(2), 138-147.

Darder, A. (1991). Culture and power: A critical foundation for bicultural education. Westport, CT: Bergin and Garvey.

Department of Education. (1997). ABET Policy Document. http://education.pwv.gov.za.

Department of Education. 1997. A National Multi-Year Implementation Plan for Adult Education and Training: Provision and Accreditation. Pretoria: National Department of Education.

Department of Education. 1998. Assessment policy in the General Education and Training Band, Grades $R$ to 9 and ABET. Pretoria: Government Printer.

Department of Education. (2001). The South African Literacy Campaign 2001: Implementation plan. Pretoria: Government Printers.

Department of Education, (2006). Ministerial Committee on Literacy. Pretoria: Government Printers.

Department of Education, (2010). Kha Ri Gude training manual for volunteers: Kha Ri Gude Literacy Campaign. Pretoria: Government Printers.

Department of Basic Education. (2007a). Literacy facilitators notes. Pretoria: Government Printers. 
Department of Basic Education, (2007b). Kha Ri Gude training manual for volunteers: Kha Ri Gude Literacy Campaign. Pretoria: Government Printers.

Freire, P. (1970). Pedagogy of the oppressed. New York: Continuum.

Freire, P. (1972). Cultural Action for freedom. Harmondsworth: Continuum

Freire, P. (1974). Education for critical consciousness. New York: Continuum.

Freire, P. (1993). Pedagogy of the City. New York: Continuum.

Freire, P. (1995). Pedagogy of Hope. Reliving Pedagogy of the Oppressed. New York: Continuum

Freire, P. (1998). Pedagogy of the Oppressed. Lanham: Rowman \& Littlefield.

Freire, P., \& Macedo, D. (1987). Literacy: Reading the word and the world. Westport, CT: Bergin \& Garvey.

Freire, P. (2005). Education for Critical Consciousness. New York: Continuum International Publishing Group.

Freire, P. (2007). Pedagogy of the oppressed. New York: Continuum.

Gillespie, CS, Ford, KL, Gillepsie, RD \& Leavell, AG. (1996). Portfolio assessment: Some questions, some answers, some recommendations. Journal of Adolescent \& Adult Literacy 39(6):480-491.

Giroux, H.A. (1988). Teachers as Intellectual: towards a Critical Pedagogy of Learning. Critical Studies in Education Series. Grandby Mass: Bergin Garvey.

Giroux, H. A. (1999). The mouse that roared: Disney and the end of innocence. Lanham, MD: Rowman \& Littlefield.

Giroux, H. A. \& Mclaren, P. (1996). Teacher education and the politics of engagement: The case for democratic schooling. In P. Leistyna, A. Woodrum, \& S.A. Sherblom (Eds.), Breaking free: The transformative power of critical pedagogy (pp. 301-331). Cambridge, MA: Harvard Educational Review.

Hooks, B. (1994). Teaching to transgress: education as the practice of freedom. New York: Routledge.

Hooks, B. (2003). Teaching community: a pedagogy of hope. London: Routledge.

Hutton, B (Ed.). (2002). Adult basic education in South Africa. Cape Town: Oxford University Press.

Jones, M \& Shelton, M. (2006). Developing your portfolio: enhancing your learning and showing your stuff. A guide to the early childhood student or profession. Oxford: Routledge, Taylor \& Francis. .

Joughin, G (Ed.). (2008). Assessment, learning and judgement in higher education. London: Springer.

Kincheloe, J. 2004a. The foundations of critical pedagogy, in Critical pedagogy. New York: Peter Lang, 45-97.

Kincheloe, J. (2004b). The knowledges of teacher education: Developing a critical complex epistemology. Teacher Education Quarterly $31(1): 49-66$.

Kincheloe, J. (2007). critical pedagogy in the twenty-first century: evolution for survival, in P. McLaren \& J. Kincheloe (Eds.). Critical pedagogy: where are we now? New York: Peter Lang, 9-43.

Kincheloe, JL. (2008). Critical pedagogy and the knowledge wars of the twenty-first century. International Journal of Critical Pedagogy 1(1):1-22.McKay, V. 2007. Adult basic education and training in South Africa. Pretoria: University of South Africa.

McLaren, P. 2000. Che Guevara, Paulo Freire, and the Pedagogy of Revolution. Lanham, Maryland: Rowman and Littlefield.

Motshekga, A. Basic Education Budget Vote Speech, 2013/14, National Assembly, Cape Town, May 72013

Michael, J.A. (2004). Models and Meaningful Learning. JVME 31 (1): 227-231.

Oxenham, J., Diallo, A., Katahoire, A., Petkova-Mwangi, A., Sall, O., (2002). Skills and Literacy training for Better Livlihoods, Africa Region Human Development Working Paper Series, The World Bank: Washington.

Palomba CA, Banta TW (1999). Assessment essentials: planning, implementing, and improving assessment in higher education. San Francisco, CA: Jossey-Bass Publishers.

Prinsloo, J \& Janks, H. (2002). Critical Literacy in South Africa: possibilities and constraints in 2002. English Teaching: Practice and Critique No.1 November: 20-38.

Quan-Baffour, K.P. (2000). A Model for the Evaluation of ABET Programmmes. Unpublished D.Ed Thesis. Pretoria: University of South Africa.

Rogers, C. G. (2002). Developing a positive approach to failure. In M. Peelo \& T. Wareham (Eds.), Failing students in higher education. London: Open University Press.

South African Institute of Race Relations. (2001). South Africa Survey 2001-2001. Johannesburg: SAIRR.

The South Africa Kha Ri Gude Mass Literacy Campaign (2012). Department of Adult Basic Education: Unisa. 